DOI $10.23859 / 2587-8344-2020-4-3-1$

\author{
Ксения Владимировна Доник \\ Европейский университет в Санкт-Петербурге \\ Санкт-Петербург, Россия \\ https://orcid.org/0000-0002-7179-5897 \\ extale@mail.ru \\ Kseniya V. Donik \\ European University at St Petersburg \\ St Petersburg, Russia \\ https://orcid.org/0000-0002-7179-5897 \\ extale@mail.ru

\section{Фигура недоверия: \\ князь А.С. Меншиков в Морском ведомстве периода реформ 1826-1828 гг.*}

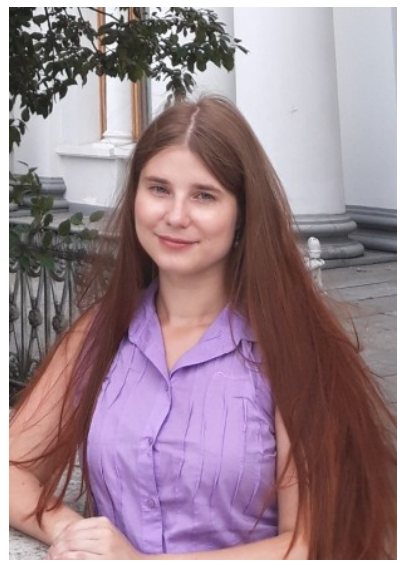

\title{
The Figure of Distrust: Prince A.S. Menshikov in the Maritime Department during the Period of Reforms, 1826-1828
}

Аннотация. В статье рассматривается роль князя А.С. Меншикова в качестве своеобразного агента верховной власти в процессе реформирования морского управления. Проблемная ситуация реформ была порождена причастностью морского генералитета и чиновников к злоупотреблениям, которые стали следствием непотизма и беспорядков во флоте. Причастность моряков к восстанию декабристов также существенно повлияла на отношение царя к общей ситуации в военно-морской среде. Николай I, испытывая недоверие к существовавшей морской администрации, нуждался в неком посреднике, который реализовывал бы его видение устройства флота, с одной стороны, а с другой, представлял бы ему объективную, «беспристрастную» картину морских проблем. Это привело к появлению во флоте ранее не имевшего отношения к морской службе генерал-адъютанта князя А.С. Меншикова, ставшего монаршим агентом, отвечающим за морские вопросы в аппарате власти самодержца. Целью статьи является попытка выявления функций такого агента на

* Для цитирования: Доник К.В. Фигура недоверия: князь А.С. Меншиков в Морском ведомстве периода реформ 1826 -1828 гг. // Historia Provinciae - Журнал региональной истории. - 2020. - Т. 4. - № 3. - С. 702-733. DOI: 10.23859/2587-8344-2020-4-3-1

For citation: Donik, K. "The Figure of Distrust: Prince A.S. Menshikov in the Maritime Department during the Period of Reforms, 1826-1828." Historia Provinciae - The Journal of Regional History, vol. 4, no. 3 (2020): 702-33, http://doi.org/10.23859/2587-8344-2020-4-3-1

(C) Доник К.В., 2020

(C) Donik K., 2020 
примере морского управления. Источниками данной статьи являются документы делопроизводственного и личного характера, некоторые из которых впервые вводятся в исследовательское поле. Основным методологическим посылом в изучении заявленной проблемы является предпринимаемая нами попытка вывести назначение Меншикова за рамки узковедомственной истории, в основе которой лежало немотивированное решение императора, и предложить интерпретацию этих событий в контексте уже описанных в историографии механизмов царского управления с помощью агентов. В статье автор приходит к выводу о взаимосвязи между ситуацией кризиса в морском управлении, отношением к нему верховной власти и появлением монаршего агента с рядом присущих ему функциональных характеристик.

Ключевые слова: Меншиков, Николай I, флот, администрация, министерство, бюрократия.

Abstract. The article considers the role of Prince A. Menshikov as a specific type of agent of supreme authority in the process of reforming the maritime administration. The problem context of reforms resulted from the involvement of the naval generals and officials in abuses, which was a consequence of nepotism and unrest in the navy. The involvement of sailors in the Decembrist revolt significantly affected the attitude of the tsar to the general situation in the naval environment. Distrustful of the existing naval administration, Nicholas I needed an intermediary who would implement his idea of the arrangement of the navy on the one hand, and provide him with an objective "impartial" account of maritime problems, on the other hand. As a result of that, Adjutant General Prince A. Menshikov, who had had nothing to do with the naval service earlier, joined the navy to become the monarch's agent in charge of the naval issues in the bodies of autocratic authority. The objective of the article is to identify the functions of such an agent based on the example of the Maritime Department. The sources of the article include official records and personal documents, some of which are introduced into scientific circulation for the first time. The principal methodological approach to the problem under study is an attempt to bring the appointment of Menshikov beyond the scope of narrow departmental history which was based on the unmotivated decision of the emperor and to propose an interpretation of the events in the context of tsarist government via agents, which has already been described in historiography. The author makes a conclusion about the interconnection between the crisis in the naval department, the attitude of the supreme authority towards it, and the appearance of the monarch's agent with a number of his own functional characteristics.

Key words: Menshikov, Nicholas I, navy, administration, ministry, bureaucracy

\section{Введение}

Административные преобразования в Морском министерстве в начале царствования Николая I в 1826-1828 гг. никогда не являлись предметом отдельного исследования. Произошедшая в этот период смена управленческих форм была достаточно радикальной: во флоте перестали существовать учреждения, основанные Петром I. Ведомство перешло на министерскую систему организации управления. Этот переход был описан еще в дореволюционной литературе, ко- 
торая с точки зрения смены государственных учреждений не усматривала в нем ничего экстраординарного': задачи морских преобразований Николая I были понятны и обоснованы. Царь хотел возродить флот и унифицировать морское управление, остающееся коллегиальным, по аналогии с военным на основании «Общего учреждения министерств». Административные преобразования воспринимались также как средство обновления состава чиновников, служащих в ведомстве, а значит, и устранения ряда негативных явлений (таких как кумовство и коррупция). Однако появление во флоте того, кто осуществлял эти преобразования - князя Александра Сергеевича Меншикова, генерал-адъютанта, впоследствии главы флота (1828-1855) $)^{2}$ - остается самым сложным для интерпретации моментом во всей истории морских административных реформ этого времени.

А.С. Меншиков явился своего рода «фигурой недоверия» Николая I к морскому генералитету и подконтрольным ему служащим департаментов. 4 декабря 1826 г., когда Меншиков представил царю свою записку о переходе к министерской системе во флоте он сделал в дневнике следующую запись: «Государь мне сказал: «Laissez venir ces gens-là à Vous et voyez ce qu'ils veuilent et ce qu'ilspensent» $^{3}$, говоря о различных морских чиновниках» ${ }^{4}$. Эта фраза императора выражала, по всей видимости, явное неудовольствие предшествующими трудами ряда ответственных лиц над вопросами создания новой администрации. Устойчивая культура персонификации власти в дореформенной России XIX в. порождала ситуацию, когда деятельность учреждений могла быть парализована, если не могла быть выполнена. Изначально для реализации программы реформирования флота, в том числе его управленческой структуры, 31 декабря 1825 г. был создан Комитет образования флота, в который входили представители морского генералитета под началом главы флота вице-адмирала А.В. Моллера (младшего). Однако Комитет, вплотную занимаясь вопросами военной части, к концу 1826 г. так и не выработал проект будущего административного устройства, фактически проигнорировав одну из задач, ради которой он создавался. Осенью 1826 г. в Кронштадте были проведены ревизии, которые вскрыли многочисленные злоупотребления, покрывавшиеся Главным команди-

${ }^{1}$ Чубинский В.Г. Историческое обозрение устройства управления Морским ведомством в России. - Санкт-Петербург: Типография Морского министерства, 1869. - С. 170-185; Огородников С.Ф. Исторический обзор развития и деятельности Морского министерства за сто лет его существования. - Санкт-Петербург: Типография Морского Министерства, 1902. C. $82-87$.

${ }^{2}$ C 1828 г. А.С. Меншиков был начальником Морского штаба Его Императорского Величества, с 1836 г. - морским министром.

3 «Пусть эти люди придут к Вам, и Вы увидите, чего они хотят и что они думают», фр.

4 Дневники князя А.С. Меншикова // Российский государственный архив военноморского флота (далее - РГА ВМФ). - Ф. 19. - Оп. 7. - Д. 134. - Л. 86. 
ром порта - контр-адмиралом Ф.В. Моллером (старшим), братом морского министра, который в итоге был лишен должности ${ }^{5}$. В довершении, к концу 1826 г. морскую администрацию расколол внутриведомственный конфликт между главой флота и генерал-интендантом В.М. Головниным. Мерой, принятой императором для разрешения сложившейся в ведомстве ситуации, стало прикомандирование генерал-адъютанта князя Меншикова официально «для помощи морскому министру в справках», а неофициально - для долгого, эмоционально дискомфортного процесса проверок, допросов, личных разговоров в кабинете царя, разжалований, унизительных неувольнений «по состоянию здоровья» и т. д. Ситуация усложнялась кумовством среди административного «верха» флота и круговой порукой чиновников среднего и мелкого звена; все звенья цепи были причастны к злоупотреблениям в отношении государственной казны ${ }^{6}$ Однако самым серьезным фактором, наложившим отпечаток на отношение царя к представителям морской администрации в это время, была широкая вовлеченность моряков в восстание декабристов: беспорядки, которые произошли 14 декабря 1825 г., политизировали беспорядок и небрежность в управлении. В этом положении Николай I выбирает того, кого он наделяет доверием быть «человеком со стороны», в этом смысле продолжая принцип персонализации, так как проявленное доверие является исключительно личным.

Почему выбор царя для проведения морских преобразований пал на представителя военно-сухопутного ведомства? Какую роль играл Меншиков с момента своего прикомандирования к Морскому министерству в конце 1826 г. до получения официально должности начальника Морского штаба в 1828 г.? Ответы на эти вопросы являются краеугольными для понимания позиции царя и функции Меншикова в процессе реформирования ведомства.

\section{Историография}

В российской историографии исследователи рассматривают практику назначения военных на министерские должности как важную составляющую механизма реализации власти самодержца в этот период ${ }^{7}$. Ставшее частью исто-

${ }^{5}$ Общий морской список. Ч. IV. - Санкт-Петербург: Типография В. Демакова, 1890. C. 386 .

${ }^{6}$ Доник К.В. Кронштадтское следствие 1827 г. и князь А.С. Меншиков: к вопросу реформирования флота в начале царствования Николая I // Историческая память России и декабристы. 1825-2015. Сборник материалов международной научной конференции (СанктПетербург, 14-16 декабря 2015 г.). - Иркутск: Иркутский областной историкомемориальный музей декабристов: Артиздат, 2015. - С. 426-435.

7 Лапин В.В. Неудачная погоня // Николай Первый. Молодые годы. Воспоминания. Дневники. Письма. - Санкт-Петербург: Пушкинский фонд, 2008. - С. 13-14; Андреева Е.А. и др. Управленческая элита Российской империи. История министерств. 1802-1917. - СанктПетербург: Лики России, 2008. - С. 177. 
рического мифа о Меншикове утверждение о якобы немотивированном назначении во флот объясняется также, как правило, в рамках мифа разве что фаворитизмом или нерациональным решением царя ${ }^{8}$. Но в данном случае, на наш взгляд, уместно говорить об особой «патримониальной рациональности», игнорирование которой существенно затрудняет понимание политического уклада того времени 9 . Это понятие, введенное В.В. Волковым в рамках исследования российских неформальных институтов, содержит возможности для более гибкой интерпретации процесса адаптации патримониальных норм к стремительной рационализации власти, в пределах идеальной и слишком контрастной модели типов господства М. Вебера. Под патримониальной рациональностью можно понимать изыскание способов сохранения личного влияния на новые бюрократизирующиеся институты ${ }^{10}$. Мы попытаемся объяснить, какие механизмы для этого использовались в реформе Морского ведомства, и как их можно распознать и квалифицировать, исходя из существующего на сегодня инструментария историографии.

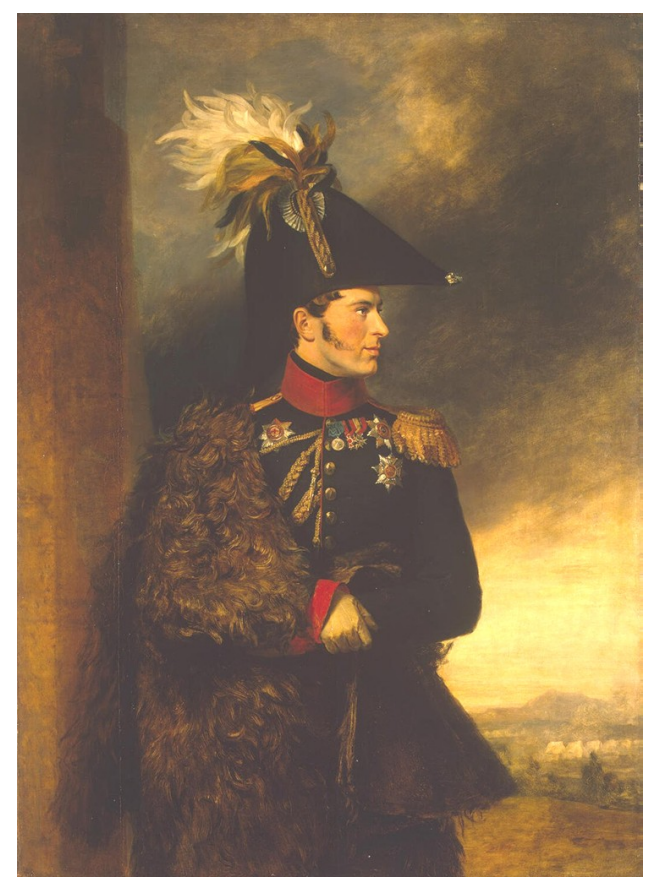

А.С. Меншиков. Портрет работы Дж. Доу, около 1825.

Источник: Государственный Эрмитаж, Санкт-Петербург. ГЭ-5130

${ }^{8}$ тарле Е.В. Крымская война: в 2 т. Т. 2. - Санкт-Петербург: Наука, 2011. - С. 82.

${ }^{9}$ Volkov V. Patrimonialism versus Rational Bureaucracy: On the historical Relativity of Corruption // Bribery and blat in Russia: negotiating reciprocity from the Middle Ages to the 1990s / edited by St. Lovell. - Houndmills, Basingstoke, Hampshire: Macmillan Press; New York: St. Martin's Press, in association with School of Slavonic and East European Studies, University of London, 2000. - P. 38-39.

${ }^{10}$ Volkov V. Patrimonialism versus Rational Bureaucracy: On the historical Relativity of Corruption. - P. 40 . 
В первую очередь должна быть отвергнута часто встречающаяся в популярно-исторических нарративах версия о князе А.С. Меншикове как «фаворите» Николая I. Феномен фаворитизма определяется в известной мере фактором случайности той или иной фигуры на политическом небосклоне. Путь Меншикова-правнука к вершине военной власти в 1820-х гг. не тождественен пути его прадеда: ни их политические траектории, ни посмертные мифические судьбы не схожи. Апокрифичной, с нашей точки зрения, является версия о романтическом характере императора, которому было лестно, что он «правит страной, имея среди своих сотрудников правнука ближайшего сподвижника Петра», а «сама история» для него повторяется ${ }^{11}$.

Как представляется, перед нами классическое явление агента монаршей власти, неформальный институт которого наряду с формированием бюрократических структур модернизирующегося государства, продолжал оставаться одним из самых быстрых и эффективных механизмов интенсификации властного ресурса. По справедливому замечанию Дж. Янея, эти институты, представляющиеся следствием и продолжением неограниченной власти, в известной степени являлись «запасным путем» формирующегося легального порядка ${ }^{12}$. В своей интерпретации формирования российской администрации в первой четверти XIX в. Дж. Яней исходил из того, что агентами являлись сенатские прокуроры и подчиненные Сенату генерал-губернаторы как проводники власти за пределами административного центра ${ }^{13}$. При Николае I, по мнению исследователя, власть таких агентов расширилась и укрепилась, однако, главным органом, курирующим их деятельность, стала Собственная Его Императорского Величества Канцелярия, заменившая всеобъемлющую деятельность А.А. Аракчеева ${ }^{14}$. На идее о Канцелярии как учреждении, функции которого распространялись далеко за пределы механической бумажной и иной исполнительной работы, построено исследование П. Мустонена. Коллективный «агент» был, с одной стороны, важным штрихом к портрету «правильного» бюрократического управления, с другой - являлся ничем иным как «продолжением воли» самодержца ${ }^{15}$. Недостатки такой администрации могли компенсироваться только временем,

${ }^{11}$ Бутенин А.В. А.С. Меншиков - государственный деятель, царедворец и человек // Из глубины времен: альманах. - Санкт-Петербург: Редакция альманаха «Из глубины времен», 1995. - Вып. 5. - С. 116-117.

${ }^{12}$ Yaney G.L. The Systematization of Russian Government: Social Evolution in the Domestic Administration of Imperial Russia, 1711-1905. - Urbana, Ill.: University of Illinois Press, 1973. P. 10 .

${ }^{13}$ Yaney G.L. The Systematization of Russian Government. - P. 221.

${ }^{14}$ Yaney G.L. The Systematization of Russian Government. - P. 222.

15 Мустонен П. Собственная его императорского величества канцелярия в механизме властвования института самодержца, 1812-1858: к типологии основ имперского управления. - [Хельсинки]: Aleksanteri inst., 1998. - С. 303. 
являвшим новых профессиональных бюрократов, этос которых лежал в области абстрактного порядка, а не персонифицированного «служения». В характеристике царствования Николая I Дж. Яней уделял особое внимание III Отделению и выполнению жандармами функций личных монарших агентов ${ }^{16}$. Введение министерской системы, с его точки зрения, немного сократило деспотическое влияние на администрацию, несмотря на то, что вчерашние «всемогущие» агенты становились ее частью, накладывая на ее работу и воспроизводство соответствующий отпечаток ${ }^{17}$.

В дальнейшем работы Д. Орловски еще раз поставили вопрос о природе невидимых внутренних связей, на которых строились взаимоотношения всех уровней министерской власти, включая самих министров. Исследователь предложил проанализировать оставшиеся следы этих взаимоотношений с учетом модели патронажа и клиентелы. В своей важнейшей статье о политическом клиентелизме в России он справедливо отмечает, что этот подход эффективен в силу «исторической важности личных взаимоотношений в культурной и институциональной жизни России» 18 . Исходя из того, что клиентелизм и прочие неформальные паттерны были встроены в институциональные системы дореволюционной России, Д. Орловски систематизировал типы клиентелизма, которые могли иметь место в государственных учреждениях. Они никогда не являлись «чистыми», встречаясь в комбинациях, но в значительной степени влияли на осуществление власти как принятия решений и управления ${ }^{19}$. «Клиентелизмы» особой близости к императору, родства (непотизм), места и служебных связей в тех или иных вариантах встречались в разных институциях и являлись структурами большой исторической длительности. Условное деление российского политического клиентелизма было поддержано Дж. Хоскингом в статье, посвященной этому феномену российской политической культуры ${ }^{20}$. Для нас, как представляется, важен четвертый вариант - клиентелизм служебных связей, который преобладал в новых административных структурах и определялся Д. Орловски через свою функциональность. По его наблюдениям, личные связи, влиявшие на карьеру сановника, формировали его окружение в учреждении и являлись главным фактором его карьеры, поскольку для повышения требовались «успешно решенные задачи», а последнее, в свою очередь, зависело от

${ }^{16}$ Yaney G.L. The Systematization of Russian Government. - P. 226-227.

${ }^{17}$ Yaney G.L. The Systematization of Russian Government. - P. 226.

${ }^{18}$ Orlovsky D.T. Political clientelism in Russia: the historical perspective // Leadership Selection and Patron-client Relations in the USSR and Yugoslavia: Selected Papers from the Second World Congress for Soviet \& East European Studies. - London: Allen \& Unwin, 1983. - P. 174.

${ }^{19}$ Orlovsky D.T. Political clientelism in Russia: the historical perspective. - P. 176-177.

${ }^{20}$ Hosking G. Patronage and the Russian state // The Slavonic and East European Review. 2000. - Vol. 78. - No. 2. - P. 301-320. 
«талантливых и преданных клиентов», т. е. исполнителей, которым эти задачи были полностью или частично делегированы ${ }^{21}$.

Опираясь на наблюдения Д. Орловски, мы склонны интерпретировать назначение князя Меншикова во флот как смену укоренившегося в адмиралтейских учреждениях непотизма на патрон-клиентскую сеть, строившуюся на личном доверии, а также разновидностях успешных личных и служебных отношений, являвшихся залогом нужного монарху порядка в ведомстве. Иными словами, верховная власть сама формировала такую сеть через своего агента, способствуя тому, чтобы на административные должности попадали люди, обладавшие доверием этого агента или самого царя. Агент по определению сам являлся «клиентом» монарха, в случае Меншикова лично обязанным за милость восстановления на службе в прежних высоких чинах в 1826 г. после опалы при Александре I (1824 г.). Такая схема становилась эффективнейшим механизмом контроля не только предпринимаемых действий, но и финансовых средств, отпускаемых в восстанавливаемый флот в колоссальных размерах ${ }^{22}$.

\section{А.С. Меншиков как «агент» монарха во флоте}

Переходя к анализу природы такого «агента» с личной сетью доверия, следует отметить, что случай Меншикова отражал распространение в этой роли в царствование Николая I свитских чинов (адъютантов). В историографии отмечалось, что Николай I формировал окружение таким образом, что в нем отсутствовали случайные лица, поэтому подбирались люди, соответствовавшие

духу «николаевских порядков», предусматривавших прежде всего исполнительность и преданность престолу, а отнюдь не инициативу и тем более свободомыслие... ${ }^{23}$

Доступ в состав ближнего окружения определялся критерием личного доверия. Особо приближенные часто носили высшие свитские звания - генерал- и флигель-адъютант. О возросшем значении Свиты при Николае I писали дореволюционные историки ${ }^{24}$. А.Е. Пресняков, в очерке «Апогей самодержавия» замечал, что функции адъютантов в Николаевское правление расширились, а их вес в обществе и администрации увеличился:

${ }^{21}$ Orlovsky D.T. Political clientelism in Russia. - P. 179.

22 Огородников С.Ф. Исторический обзор развития и деятельности Морского министерства. - С. 130.

${ }^{23}$ Власть и реформы: от самодержавной к советской России / под редакцией Б.В. Ананьича. - Санкт-Петербург: Дмитрий Буланин, 1996. - С. 272.

${ }^{24}$ Столетие Военного министерства. 1802-1902. Императорская главная квартира. История государевой Свиты. Царствование Императора Николая I: в 13 т. Т. 2. - СанктПетербург: Типография товарищества М.О. Вольфа, 1908. - С. 7-117. 
Своих генерал- и флигель-адъютантов Николай I держал в близости и милости, но очень сурово наказывал даже за сравнительно маловажные проступки. Недоверчивый и подозрительный, он верил чинам своей свиты, видел в них людей, которые знают его взгляды и желания и готовы беспрекословно проводить их в жизнь, притом не за страх, а за совесть. Туда, куда ему хотелось проникнуть личным наблюдением и личной распорядительностью, он их посылал, своих генерал- и флигельадъютантов. Они должны были быть постоянно готовыми к отъезду в командировки по самым разнообразным и часто щекотливым поручениям. Через них Николай держал в своих руках управление армией, посылал их на осмотр воинских частей, на контроль над рекрутскими наборами и т. п.; их рассылал он на производство следствий о злоупотреблениях в военном и гражданском хозяйстве, требуя подробных отчетов лично себе. Такие командировки были средством прямого вмешательства верховной власти во всякие дела и вопросы: по расследованию о действиях гражданских и военных властей... ${ }^{25}$

С нашей точки зрения, текст А.Е. Преснякова содержит самые точные составляющие для определения агента. На адъютантов из Свиты как на один из самых часто используемых и эффективных инструментов власти, в историографии обращалось мало внимания. Универсальность роли адъютантов делает уязвимым всякое обобщающее суждение об их функционале. В Николаевское царствование адъютанты Свиты имели разные судьбы и мотивации для службы в свитском звании; иногда оно становилось почетным и не влекло никаких, по выражению А.Е. Преснякова, «щекотливых поручений». Однако те, на кого возлагались эти «щекотливые поручения», по всей видимости, наделялись личнылм доверием монарха. И чем оно было выше, тем более могло снижаться влияние формальных институтов той сферы, которая была такому «агенту» поручена. Доверие, вероятно, стоит определять как основу природы приближенного агента; а его появление в качестве ревизора или контролера изменяло поведение чиновников, которые сталкивались с ним уже как с «фигурой недоверия» к ним монарха.

Князь А.С. Меншиков после своей отставки 24 ноября 1824 г. был возвращен на службу по личному прошению, удовлетворенному императором, и восстановлен в высшем свитском звании генерал-адъютанта 10 октября 1826 г. $^{26}$ В этом качестве он входил в небольшой круг тех, кто потенциально мог рассчитывать на личное поручение в решении разных ответственных задач.

Однако появление Меншикова во флоте можно рассматривать и в более широком аспекте - во влиянии порядков сухопутного ведомства на морское управление: вместе с ним во флот на административно-военные должности

25 Пресняков А.Е. Апогей самодержавия // Российские самодержцы / составитель А.Ф. Смирнов. - Москва: Книга, 1990. - С. 286-287.

26 Формулярные списки князя А.С. Меншикова и отставка // РГА ВМФ. - Ф. 19. Оп. 4. - Д. 791.- Л. 66 об. 
пришла часть офицеров Главного штаба и канцелярских чиновников Военного министерства. Назначение военных в «критические» сферы является яркой характерной чертой высшей администрации при Николае I. Это уже более обоснованный и хорошо описанный в историографии факт ${ }^{27}$. Военное ведомство, ставшее образцом при реформировании Морского, было централизованным и структурированным: именно его порядок должны были реализовать Меншиков и его помощники во флоте.

Назначение военных или свитских «агентов» доверенными лицами при Николае I для решения важных вопросов следует рассматривать в контексте общей подготовки бюрократического аппарата и низкой эффективности его работы в то время. В правление Александра I появились новые институты, придавшие черты «европейскости» административным структурам, однако, проблема нехватки квалифицированных чиновников, которые служили бы абстрактным идеалам законов и порядка, новыми административными формами, правилами и инструкциями еще не была решена. В поствеберианских исследованиях бюрократии, в частности у П. Блау, отмечалось, что «основанное на бюрократических правилах и дисциплине отправление власти необходимо отличать от власти, которая зиждется на профессиональной квалифицированности» ${ }^{28}$. До профессиональной зрелой бюрократии в конце 1820-х гг. было еще весьма далеко, однако, потребность государства в прозрачном и эффективном управлении, которое бы как можно меньше зависело от влияния личных связей и непотизма, в реалиях усложнения государственного управления была достаточно большой. Основной чертой бюрократического управления является безличность, отсутствие взаимосвязи между решениями и личными интересами чиновника. В литературе описаны примеры повышения уровня бюрократизации в организации при смене руководителей «в силу того, что незнакомый с неформальной практикой руководитель вынужден полагаться на официальные способы выполнения его приказов» ${ }^{29}$. В ситуации недоверия источника власти (императора) к целой административной структуре принцип назначения ранее не имевшего отношения к данной сфере управленца может истолковываться как вполне эффективная технология достижения нужного верховной власти результата.

Таким образом, агент 1820 -1830-х гг. может рассматриваться как инструмент еще во многом «ручного» механизма, но которым, в частности была сформирована вполне качественная, устранившая засилье личных влияний и

${ }^{27}$ Lincoln W.B. Nicholas I, Emperor and Autocrat of all the Russians 1796-1855. - Bloomington; London: Indiana University Press, 1978. - P. 99-100.

${ }^{28}$ Блау П.М. Исследования формальных организаций // Американская социология. Перспективы. Проблемы. Методы. - Москва: Прогресс, 1972. - С. 102.

${ }^{29}$ П.М. Блау со ссылкой на исследования Э.У. Гоулднера. См.: Блау П.М. Исследования формальных организаций. - С. 102. 
интересов бюрократическая структура Морского министерства. В известной степени это подтверждает тезис о том, что патримониальное управление может не только развивать в себе «бюрократические черты» ${ }^{30}$, но и на определенном уровне развития создавать качественные административные системы рационального типа. Какие функции были у таких агентов и какие задачи они выполняли?

Идея «сухопутного» управляющего во главе флота (или только хозяйственной его части), вопреки всем историческим анекдотам о Меншикове, допускалась представителями морского сообщества, по крайней мере, проговаривалась ими. Так, мысли о «сухопутном» генерале можно найти в «Записке о состоянии российского флота в 1824 г.» В.М. Головнина ${ }^{31}$, специальных записках, созданных моряком-декабристом Д.И. Завалишиным для рассмотрения их в Комитете образования флота ${ }^{32}$. Однако император, помимо решения управленческих задач, определил Меншикова к занятиям морскими делами в конце ноября 1826 г., преследуя свою цель: князь должен был стать своего рода ревизором морской администрации, не имея к ней никакого личного отношения или связей. И понимание именно этой роли Меншикова, по словам одного из мемуаристов, приводило к недовольству морского сообщества, являвшегося «как бы отдельным государством» ${ }^{33}$. Другой мемуарист описывал технику назначения мнимых «товарищей» действующим министрам в качестве испытанного способа удаления последних от власти в той ситуации, когда царь переставал им доверять $^{34}$. Как представляется, подобное положение Меншикова было полезно для верховной власти.

Фигура агента императора создавала видимость отстраненности императора от происходящего. В этой новой сценарной ситуации, главным инициатором которой был император, вчерашние заслуженные адмиралы стали объектом недоверия, проверок и взысканий. В истории преобразований морского ведомства Николай I всегда играл основную роль, что неизбежно должно было вовлекать его в межличностные конфликты, в том числе связанные с коррупцией, злоупотреблениями властью, несоблюдением предписаний, незаконными увольнениями «неугодных» и т. д. Однако, это был тот спектр вопросов, которыми не подобало заниматься монарху. Так, в январе-феврале 1827 г. Николай I уделял

${ }^{30}$ Volkov V. Patrimonialism versus Rational Bureaucracy. - P. 38.

31 Мичман Мореходов [Головнин B.M.]. О состоянии Российского флота в 1824 году. Санкт-Петербург: Типография Морского министерства, 1861. - С. 63.

32 О рассмотрении в Комитете образования флота записок лейтенанта Завалишина, заключающих замечания об образовании флота и др. // РГА ВМФ. - Ф. 148. - Оп. 1. - Д. 148. Л. 3.

33 Фишер К.И. Записки сенатора. - Москва: Захаров, 2008. - С. 77.

${ }^{34}$ Вигель Ф.Ф. Записки. - Москва: Захаров, 2000. - С. 312. 
много времени Кронштадту, лично осматривая порт. 17 января 1827 г. А.Х. Бенкендорф писал М.С. Воронцову о том, что адмирал Моллер (старший)

был отстранен от своих должностей в Кронштадте и уволен за открытые и доказанные злоупотребления в его администрации. Сегодня император только что уехал в Кронштадт, где он явится как снег на голову; его сопровождает один Меншиков, которому поручено привести в порядок адмиралтейские канцелярские дела. Это отличный выбор и это то, что он усердно и постоянно изучал... 35

Через несколько дней, 22 января, в своем дневнике Меншиков сделал запись о том, что он по приказу цзаря требовал справки у Моллера о причине увольнения одного корабельного мастера ${ }^{36}$.

По мере вхождения Меншикова в морские дела уровень видимого личного присутствия (но не участия) императора снижался, создавая иллюзию его отстраненности от морской группы интересов. Однако любая ситуация конфликта или нелояльности действиям самого агента обнажала уязвимость и суть его природы. Так, когда во время отсутствия А.С. Меншикова в Петербурге на его действия во флоте был написан анонимный донос, первый его «клиент» флигель-адъютант В.А. Перовский умолял императора не собирать адмиралов с целью установить автора доноса: во-первых, это бы заставило всех думать, что император верит доносам, а во-вторых, проявляет недоверие к Меншикову и позволяет обсуждать его решения ${ }^{37}$. Николай I, вняв доводам В.А. Перовского, передумал, так как на самом деле обсуждение действий Меншикова в кругу адмиралов по доносу в конечном итоге означало бы критику его собственных решений и его личного выбора Меншикова в качестве главы флота. Донос было решено оставить без внимания.

Личное участие императора в решении конфликтных ситуаций ставило проблему ответственности монарха за принимаемые решения, а также привлечения его имени к нелицеприятному контексту. В деле осведомления Николай I опирался на аппарат созданной им полиции, а для недопущения общественного порицания существовали агенты, одним из которых стал Меншиков. Князь понимал назначение своей роли. Спустя многие годы, в 1857 г., составляя комментарии к проекту реформы ведомства при великом князе Константине Николаевиче, он остерегал генерал-адмирала от непосредственного руководства хозяйственной частью флота, денежные и подрядные дела которой не должны

${ }^{35}$ Письмо А.Х. Бенкендорфа - М.С. Воронцову. Петербург, 17 января 1827 года // Архив князя Воронцова: в 40 кн. - Москва: Университетская типография, 1889. - Кн. 35. - С. 272.

${ }^{36}$ Дневники князя А.С. Меншикова // РГА ВМФ. - Ф. 19. - Оп. 7. - Д. 134. - Л. 88 об.

37 Дело об анонимном доносе на князя Меншикова с резолюциями государя // РГА ВМФ. - Ф. 19. - Оп. 4. - Д. 74. - Л. 21 об. 
были касаться имени члена императорской семьи ${ }^{38}$. На волне либеральных преобразований такая позиция воспринималась ретроградной, отражающей «отсталость» взглядов того, кто олицетворяя собой военно-морское управление, имел к тому же отрицательный опыт командования армией в ходе Крымской войны. Но позиция Меншикова отражала опыт его пребывания в администрации отца великого князя. В 1827 г., когда великий князь появился на свет, Меншиков постепенно становился той фигурой, которая в глазах общества и в официальных документах несла ответственность за все происходившее с флотом; при этом драма его положения заключалась в том, что сам князь Меншиков скорее выполнял возложенные на него поручения (особенно в первые годы реформ, в 1826-1828 гг.), нежели поступал в соответствии со своими взглядами на тот или иной предмет. Царь действовал через него, вникая в те дела, которые могли бы расцениваться как недостойные «высочайшего внимания».

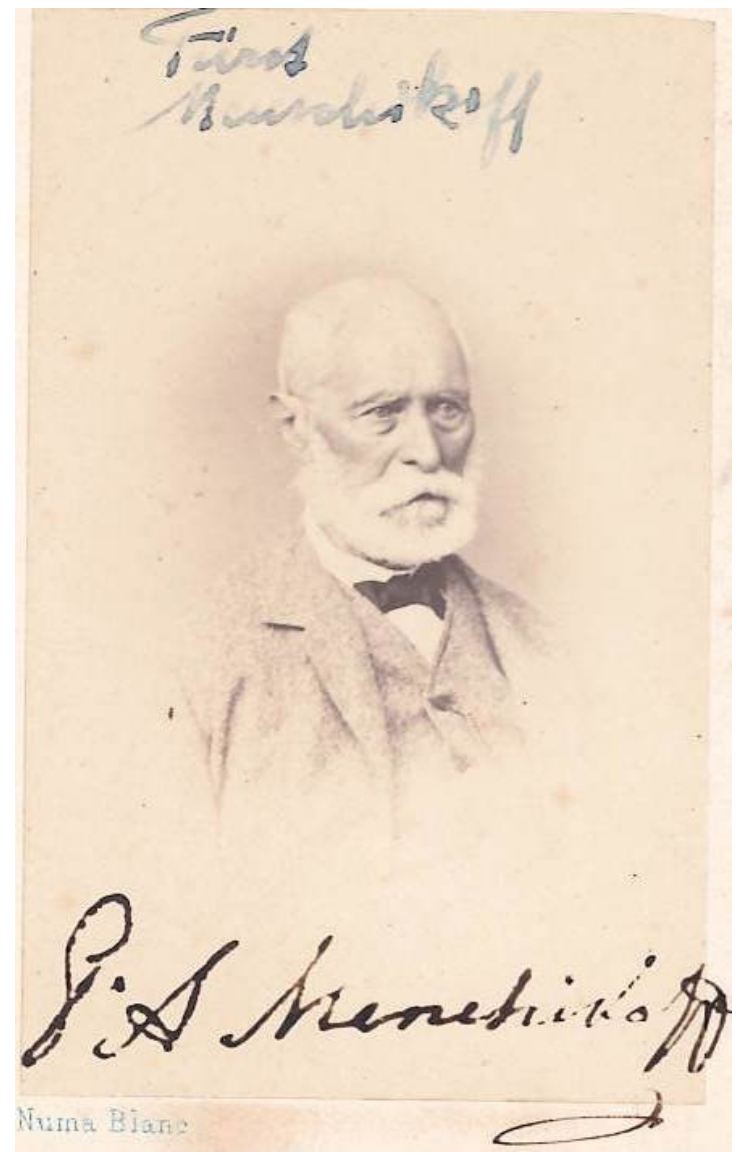

Князь А.С. Меншиков, 1860-е гг.

Источник: Из личного архива К.В. Доник. Публикуется впервые

38 Замечания князя Меншикова по составлению проекта преобразования Морского министерства // РГА ВМФ. - Ф. 19. - Оп. 1. - Д. 331. - Л. 35 об.; Доник К.В. Князь А.С. Меншиков и административные преобразования в Морском ведомстве в конце 50-х гг. XIX столетия // Александр II и его время. К 200-летию со дня рождения: сборник статей / под редакцией В.В. Яковлева. - Санкт-Петербург: РГПУ им. А.И. Герцена, 2019. - С. 143-155. 
Проблема возможной личной критики обществом самого монарха и его решений была описана М.Ф. Флоринским на материале начала XX в. ${ }^{39}$ Являясь своего рода платой за неограниченную никакими институтами власть самодержца, она заключалась в том, что «соответствующие повеления по крайней мере внешне выглядели как плоды личной инициативы царя со всеми вытекающими отсюда последствиями» ${ }^{40}$. При Николае I вмешательство верховной власти в работу административно-бюрократической системы усилилось, так как император стремился заставить ее «добросовестно выполнять свои обязанности» ${ }^{41}$, но вместе с этим возросло и бремя его личной ответственности. Поэтому функцию Меншикова можно сравнить с условной «ширмой», которая обеспечивала видимость непричастности монарха и одновременно секретность, в которой предпочитал действовать Николай I.

Это не означает, что никто не догадывался о том, что происходило в Морском министерстве (об этом свидетельствуют некоторые мемуаристы), но, как кажется, это не проговаривалось в контексте личной заинтересованности монарха, личных решений вопреки представлениям о справедливости или о том, как принято. Прежде всего, в кругу самих моряков. А поскольку в действительности миссия Меншикова была личнылм поручением царя разобраться с морским непотизмом, коррупцией и реформой одновременно, она не вписалась ни в какой историографический сценарий объяснения его действий.

Позиция агента с самого начала своего существования структурировала также должностной доступ к императору, который сознательно создавал практику передачи указов главе флота Моллеру через Меншикова. С первого рескрипта на имя начальника морского штаба от 4 декабря 1826 г., сообщающего о поручении Меншикову состоять при нем ${ }^{42}$, черновики указов, рескриптов и иных «ответов» Николая I готовились Меншиковым, утверждались царем и отправлялись Моллеру через Меншикова. Николай I читал все черновики Меншикова, вносил поправки и подписывал, если это требовалось. Черновики, как и копии монарших указов, Меншиков сохранял у себя, не передавая в морские канцелярии; особо важные, секретные документы император возвращал с резо-

39 Флоринский М.Ф. Самодержавие, бюрократия и проблема безответственности монарха в XIX - начале XX века // Историческое познание: традиции и новации: материалы Международной теоретической конференции (Ижевск, 26-28 октября 1993 г.). Ч. 2. - Ижевск: Удмуртский университет, 1996. - C. 5-14. - URL: http://annales.info/rus/19/florinskiy.htm (Дата обращения - 25.04.2020)

40 Флоринский М.Ф. Самодержавие, бюрократия и проблема безответственности монарха в XIX - начале XX века.

${ }^{41}$ Флоринский М.Ф. Самодержавие, бюрократия и проблема безответственности монарха в XIX - начале XX века.

42 О назначении князя Меншикова для преобразования Морского министерства // РГА ВМФ. - Ф. 19. - Оп. 4. - Д. 17. - Л. 17. 
люцией, специально оговаривающей их недопуск в делопроизводство или архив. Положенный по должности Моллеру как морскому министру и начальнику штаба доклад императору фактически дублировался еженедельными докладами Меншикова по предметам его миссии.

Наконец, особо следует оговорить последнюю функцию агента, которая была связана собственно с выполнением самого поручения. Вновь апеллируя к вышеприведенной историографии об адъютантах, необходимо подчеркнуть, что возлагаемые на них задачи были совершенно разными ${ }^{43}$. Князю А.С. Меншикову было поручено создание административной структуры морского управления по тому плану, который был адаптирован для Морского ведомства самим императором. Это поручение он выполнял сначала на бумаге, создавая законодательную основу функционирования аппарата будущего министерства, а затем - на практике, переводя все ведомство на новые организационные рельсы. Одновременно он курировал все сенатские и адъютантские ревизии, которые проводились в это время, докладывая об их течении императору.

Реализация столь масштабной задачи была невозможна без надежной опоры на помощников, стоящих на более низких ступенях административной лестницы. Для ее решения сам агент также формировал инструментарий, представленный сочетанием формально-бюрократических и неформальных элементов. Князь А.С. Меншиков известен в историографии тем, что «затеял перестановки в системе Военно-морского ведомства» ${ }^{44}$, однако, анатомия нового ведомства и природа «перестановок» справедливо заслуживают отдельного исследования.

Как воспринимали сами моряки монаршего агента без должности, занимающегося морскими реформами? По свидетельству К.И. Фишера, известного мемуариста, сенатора, в конце 1820 -х гг. состоявшего при князе по особым поручениям, Меншиков понимал, что его пребывание в роли реформатора флота не может нравиться старым морякам ${ }^{45}$.

Однако понимание того, что Меншиков наделен доверием и практически неограниченным доступом к государю привело глав экспедиций, департаментов и канцелярий к примирению с фактом его вторжения в «отдельное государство». Чиновники обязаны были сообщать ему предмет своих занятий. В своем дневнике в записях за декабрь 1826 г. князь отмечал дни посещения его разными морскими чиновниками ${ }^{46}$. Таким образом, Меншиков уже в начале 1827 г. стал главной фигурой во флоте, положение которой определялось монаршим доверием и поручением.

\footnotetext{
43 Пресняков А.Е. Апогей самодержавия. - С. 293.

${ }^{44}$ Ананьич Б.В. Власть и реформы. - С. 273.

${ }^{45}$ Фишер К.И. Записки сенатора. - С. 77.

${ }^{46}$ Дневники князя А.С. Меншикова // РГА ВМФ. - Ф. 19. - Оп. 7. - Д. 134. - Л. 86.
} 


\section{Заключение}

Подводя итог вышесказанному, следует заметить, что реформа 18261828 гг. была уникальной ситуацией в истории флота, сохранившей след о себе в документальных свидетельствах личного архива князя А.С. Меншикова. Требование Николаем I абсолютной секретности всех деталей происходившего во флоте за фасадом административной реформы, естественно, способствовало тому, что роль князя А.С. Меншикова представлялась более чем неизвестной, а в контексте его не морского прошлого - нелогичной. Историография имперского времени не могла сказать большего, находясь в рамках официального историописания. Тем не менее, даже обнаружение и анализ всех обстоятельств появления Меншикова в Морском министерстве, его первых шагов в администрации, взаимоотношений с царем и морской элитой не приводит к простой и однозначной трактовке связанных с его фигурой событий. Они предполагают поиск соответствующих моделей интерпретации в ряде существующих на сегодня историографических концепций, обрекая построение на эклектичность терминологии и подходов.

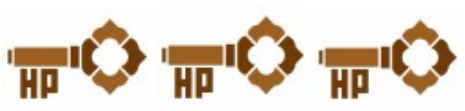

\section{Introduction}

Administrative transformations in the Naval Ministry in 1826-28 at the beginning of the reign of Nicholas I have never been the subject of a separate study. Change in administrative forms which took place at that time was quite radical: the institutions founded by Peter the Great in the navy ceased to exist. The department switched to the ministerial system of administration. That transfer was described even in prerevolutionary literature which found nothing extraordinary in it in terms of the change of state institutions: ${ }^{1}$ the tasks of the Nicholas I's naval reforms were clear and justified. The tsar wanted to revive the navy and to unify the naval administration which still remained collective by analogy with the military administration in compliance with the manifesto "On the Establishment of Ministries." Administrative reforms were also thought of as a means of renewing the staff of the officials in service

${ }^{1}$ V.G. Chubinskii, Historical Review of the Management of the Maritime Department in Russia [in Russian] (St Petersburg: Tipografiya Morskogo ministerstva, 1869), 170-85; S.F. Ogorodnikov, Historical Review of the Development and Activities of the Naval Ministry for a Hundred Years of Its Existence [in Russian] (St Petersburg: Tipografiya Morskogo Ministerstva, 1902), 82-87. 
at the department and therefore of eliminating a number of negative phenomena (such as nepotism and corruption). However, the appearance of a person who would conduct the transformations - Prince Alexander Menshikov, Adjutant General, the head of the navy later on $(1828-55)^{2}$ - remains the point which is most difficult to interpret in the entire history of maritime administrative reforms of the time.

A. Menshikov was a kind of "figure of Nicholas I's distrust" of the naval generals and departmental officials subordinate to them. On December 4, 1826, when Menshikov presented to the tsar his memorandum on switching to the ministerial system in the navy, he made the following entry in his diary: "The sovereign told me, 'Laissez venir ces gens-là à Vous et voyez ce qu'ils veuilent et ce qu'ilspensent,", while speaking about different naval officials." ${ }^{4}$ Most probably, this phrase of the emperor expressed obvious dissatisfaction with the previous work of a number of officials at the issues of establishing the new administration. Sustainable culture of personifying the authority in pre-reform Russian in the $19^{\text {th }}$ century begot the situation when the activities of institutions could be paralyzed unless they were fulfilled. Initially, on December 31, 1825 the Committee to Organize the Fleet including its administrative structure was formed in order to implement the program of naval reform. The committee included the representatives of naval generals headed by Vice Admiral A. Moller (junior). Although the committee was closely dealing with military issues, by the end of 1826 it had not worked out a draft of the future administrative structure and thus actually ignored one of the tasks it was established for. In the fall of 1826, audits were conducted in Kronstadt and revealed numerous abuses which were covered up by the chief commander of the port Rear Admiral F. Moller (senior), brother of the naval minister, who was eventually stripped of his post. To top it off, at the end of 1826 naval administration was split by an intradepartmental conflict between the head of the fleet and Intendant General V. Golovnin. ${ }^{5}$ The measure taken by the emperor in order to resolve the situation in the department was that Adjutant General Prince Menshikov was officially assigned to the naval minister "to assist in information" and unofficially he was charged with long, emotionally uncomfortable process of inspections, interrogations, personal conversations in the tsar's office, demotions, humiliating dismissals "for health reasons," etc. The situation was complicated by nepotism among the administrative "top" of the navy and the mutual guarantee of middle-rank and small officials; all links in the chain were involved in abuses

${ }^{2}$ From 1828 A.S. Menshikov was Chief of the Naval Staff to His Imperial Majesty and in 1836 he became Minister of the Navy.

${ }^{3}$ Let these people come to You and You will see what they want and what they think.

${ }^{4}$ Dnevniki knyazya A.S. Menshikova [Diaries of Prince Menshikov]. F. 19, op. 7, d. 134, 1. 86. Rossiiskii gosudarstvennyi arkhiv voenno-morskogo flota [Russian State Archive of the Navy] (RGA VMF), St Petersburg, Russia.

${ }^{5}$ Comprehensive Maritime List [in Russian], pt. 4 (St Petersburg: tipografiya V. Demakova, 1890), 386. 
of the state treasury. ${ }^{6}$ However, the most serious factor that influenced the tsar's attitude towards the representatives of the naval administration at the time was the wide involvement of sailors in the Decembrist revolt: unrest which occurred on December 14,1825 politicized disorder and negligence in management. In this situation Nicholas I chose the person who he vested with trust to be an "outsider" and in doing so he continued the principle of personalization, since the trust of the tsar was exclusively personal.

Why did the tsar choose a representative of the land forces to carry out naval reforms? What role did Menshikov play from the moment he was appointed to the naval ministry at the end of 1826 until he officially took the position of Chief of the Naval Staff in 1828 ? The answers to these questions are fundamental in understanding the position of the tsar and the function of Menshikov in the process of reforming the department.

\section{Historiography}

In Russian historiography, researchers consider the practice of appointing military personnel to ministerial posts as an important component of the mechanism for exercising the power of the autocrat during that period. ${ }^{7}$ The statement about the allegedly unmotivated appointment to the navy, which has become part of the historical myth about Menshikov, is usually explained in terms of that same myth by favoritism or by an irrational decision of the tsar. ${ }^{8}$ But in our opinion in this instance it can be appropriate to talk about special "patrimonial rationality," ignoring which, it would be more difficult to understand the political structure of that time. ${ }^{9}$ This concept, introduced by V. Volkov within the framework of the study of Russian informal institutions, offers opportunities for a more flexible interpretation of the process of adapting patrimonial norms to the rapid rationalization of power, within the framework of the ideal and too contrasting model of the types of domination by M. Weber. Patrimonial

${ }^{6}$ K.V. Donik, "The Kronstadt Investigation of 1827 and Prince A.S. Menshikov: on the Issue of Reforming the Fleet at the Beginning of the Reign of Nicholas I" [in Russian], in Historical Memory of Russia and the Decembrists. 1825-2015. Collected Papers of the International Scientific Conference (St Petersburg, December 14-16, 2015) (Irkutsk: Irkutskii oblastnoi istorikomemorial'nyi muzei dekabristov: Artizdat, 2015), 426-35.

${ }^{7}$ V.V. Lapin, "Unfortunate Chase" [in Russian], in Nicholas I of Russia. Early Years. Reminiscences. Diaries. Letters (St Petersburg: Pushkinskii fond, 2008), 13-14; E.A. Andreeva et al., Administrative Elite of the Russian Empire. The History of Ministries. 1802-1917 [in Russian] (St Petersburg: Liki Rossii, 2008), 177.

${ }^{8}$ E.V. Tarle, The Crimean War [in Russian], 2 vols., vol. 2 (St Petersburg: Nauka, 2011), 82.

${ }^{9}$ V. Volkov, "Patrimonialism versus Rational Bureaucracy : On the Historical Relativity of Corruption," in Bribery and Blat in Russia: Negotiating Reciprocity from the Middle Ages to the 1990 s, ed. St. Lovell (Houndmills, Basingstoke, Hampshire: Macmillan Press; New York: St. Martin's Press, in association with School of Slavonic and East European Studies, University of London, 2000), 38-39. 
rationality can be understood as finding ways to maintain personal influence on new institutions which are becoming more and more bureaucratized. ${ }^{10}$ We will try to explain what mechanisms were used in order to do that during the reform of the Maritime Department and how they can be recognized and qualified based on the existing historiography.

The assumption to be rejected first of all is the frequently mentioned in popular historical narratives fact that Prince A. Menshikov was a "favorite" of Nicholas I. To a certain extent, the phenomenon of favoritism is determined by the factor of randomness of a particular figure in the political horizon. The path of Menshikov Great Grandson to the pinnacle of military power in the 1820s is not identical to that of his great-grandfather: neither their political trajectories, nor posthumous mythical destinies are similar. From our point of view, the assumption about the romantic character of the emperor, who was flattered that he "ruled the country, having among his employees the great-grandson of the closest associate of Peter the Great" and "history repeats itself" for him, ${ }^{11}$ is apocryphal.

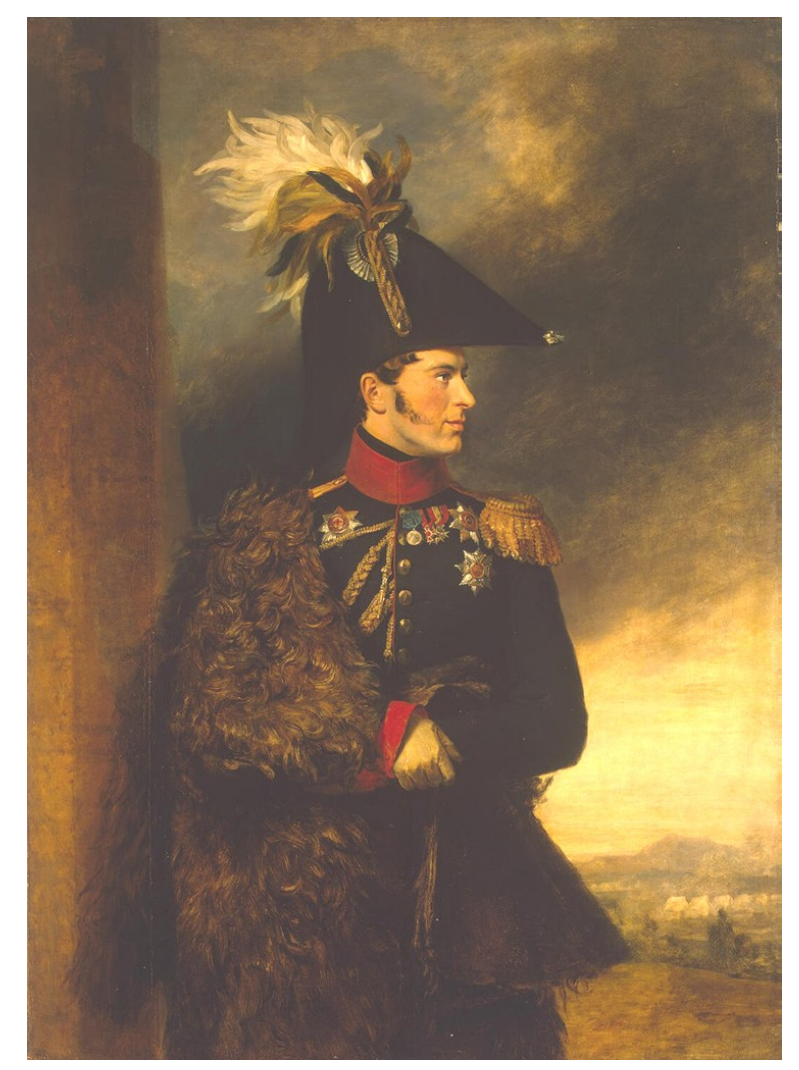

A.S. Menshikov. Portrait by G. Dawe, circa 1825.

Source: The State Hermitage Museum, St Petersburg. GE-5130.

${ }^{10}$ Volkov, "Patrimonialism versus Rational Bureaucracy," 40.

11 A.V. Butenin, "A.S. Menshikov, a Statesman, a Courtier, and a Person” [in Russian], in From the Depths of Time: an Almanac, iss. 5 (St Petersburg: Redaktsiya al'manakha "Iz glubiny vremen", 1995), 116-17. 
It seems that we can see the classic phenomenon of an agent of monarchical power. Along with the formation of bureaucratic structures of the state undergoing modernization, that informal institution remained one of the fastest and most effective mechanisms for intensifying the resource of authority. As G. Yaney pointed out, the institutions which appeared to be a consequence and continuation of unlimited power, to a certain extent were a kind of sidetrack for the emerging legal order. ${ }^{12} \mathrm{G}$. Yaney's interpretation of how Russian administration was formed in the first quarter of the $19^{\text {th }}$ century proceeds from the assumption that the agents were senate prosecutors and governor generals subordinate to the Senate who acted as conductors of authority outside the administrative center. ${ }^{13}$ According to the scholar, under Nicholas I the power of such agents expanded and grew stronger and the main agency to supervise their activities was His Imperial Majesty's Own Chancery which replaced the allembracing activity of A. Arakcheev. ${ }^{14}$ P. Mustonen's research is based on the idea of the Chancery as an institution whose functions go far beyond mechanical paperwork and other types of executorial work. On the one hand, a collective "agent" was an important component in the image of the "correct" bureaucratic government, and on the other hand it was nothing other than the "extension of the will" of the autocrat. ${ }^{15}$ The drawbacks of that system could be compensated for only with the time which gave birth to new professional bureaucrats whose ethos was in the sphere of certain abstract order rather than personified "service." When characterizing the reign of Nicholas I, G. Yaney paid special attention to the Third Section of His Imperial Majesty's Own Chancery and to how the gendarmes performed the functions of the monarch's personal agents. ${ }^{16}$ From his point of view, the introduction of ministerial system reduced the despotic impact on the administration despite the fact that yesterday's omnipotent agents became a part of it, thus leaving a corresponding imprint on its activities and reproduction. ${ }^{17}$

Later on, the works by D. Orlovsky raised the issue of the nature of the invisible internal connections on which all levels of authority were based, including the ministers themselves. The researcher proposed to analyze the remaining traces of those relationships taking into account the model of patronage and clientele. In his significant article about political clientelism in Russia, he noted that this approach is effective because of historical importance of personal relationships in cultural and institutional

${ }^{12}$ G.L. Yaney, The Systematization of Russian Government: Social Evolution in the Domestic Administration of Imperial Russia, 1711-1905 (Urbana, Ill.: University of Illinois Press, 1973), 10.

${ }^{13}$ Yaney, The Systematization of Russian Government, 221.

${ }^{14}$ Yaney, The Systematization of Russian Government, 222.

${ }^{15} \mathrm{P}$. Mustonen, His Imperial Majesty's Own Chancery in the Mechanism of Autocrat Rule, 1812-1858: on the Typology of the Foundations of Imperial Government [in Russian] ([Helsinki]: Aleksanteri inst., 1998), 303.

${ }^{16}$ Yaney, The Systematization of Russian Government, 226-27.

${ }^{17}$ Yaney, The Systematization of Russian Government, 226. 
life of Russia. ${ }^{18}$ Proceeding from the fact that clientelism and other informal patterns were integrated in the institutional systems of pre-revolutionary Russia, D. Orlovsky systematized the types of clientelism which might have taken place in government institutions. They were never pure and were found in combinations, but they greatly influenced the implementation of power as decision-making and governance. ${ }^{19}$ The clientelism of special closeness to the emperor, of place and relations of service, and nepotism in some or other forms existed in different institutions and was a phenomenon of long historical duration. Conventional division of Russian political clientelism was supported by G. Hosking in an article devoted to this phenomenon of Russian political culture ${ }^{20}$ The fourth form seems of importance for us. It is the clientelism of official relations, which prevailed in new administrative structures and was determined by D. Orlovsky through his functionality. According to him, personal connections which influenced the career of a dignitary shaped his environment in the institution and were the main factor of his career, since promotion required successfully accomplished tasks, and the latter, in their turn, depended on "talented and loyal clients," i.e. the executors who those tasks were fully or partially delegated to. ${ }^{21}$

Based on the observations of D. Orlovsky, we incline to interpret the appointment of Prince Menshikov to the navy as a replacement of nepotism, which was rooted in the admiralty institutions, with a patron-client network built on personal trust and various successful personal and official relations which were a guarantee for order the monarch needed in the department. In other words, the supreme power itself formed such a network by means of its agent, ensuring that administrative positions were held by the people who had the trust of this agent or the tsar himself. The agent was a "client" of the monarch by definition, and in the instance of Menshikov he was personally indebted for the mercy of being reinstated in the service in his former high ranks in 1826 after disgrace under Alexander I (1824). Such scheme became an effective mechanism of control both over the actions taken and financial resources allocated in huge amounts to restore the navy. ${ }^{22}$

${ }^{18}$ D.T. Orlovsky, "Political Clientelism in Russia: the Historical Perspective," in Selected Papers from the Second World Congress for Soviet \& East European Studies (London: Allen \& Unwin, 1983), 174.

${ }^{19}$ Orlovsky, "Political Clientelism in Russia," 176-77.

${ }^{20}$ G. Hosking, "Patronage and the Russian State," The Slavonic and East European Review, vol. 78, no. 2 (2000): 301-20.

${ }^{21}$ Orlovsky, Political Clientelism in Russia, 179.

${ }^{22}$ Ogorodnikov, Historical Review of the Development and Activities of the Naval Ministry, 130. 


\section{A. Menshikov as the monarch's "agent" in the navy}

Coming to the analysis of such an agent with the personal network of trust, we should point out that the instance of Menshikov exemplified the fact that during the reign of Nicholas I that role was common among the retinue officials (adjutants). Historiography mentions that Nicholas I selected his entourage in such a way that there were no come-and-go people there; that is why only those persons were selected who

corresponded to the spirit of the "order established by Nicholas" which implied assiduity and loyalty to the throne first of all but not at all required initiative and free thinking. . . ${ }^{23}$

Access to the close circle was determined by the criterion of personal trust. Those particularly close to the emperor often had the highest courtier ranks of general adjutant and flügel adjutant. Pre-revolutionary historians wrote about the increased importance of the retinue at the time of Nicholas I. ${ }^{24}$ In the essay "The Apogee of Autocracy" A. Presnyakov pointed out that the functions of the adjutants expanded and their weight in society and administration increased:

Nicholas I kept his general adjutants and flügel adjutants in close proximity and mercy, but punished them very severely even for relatively minor faults. Distrustful and suspicious, he believed his entourage and saw them as people who knew his views and desires and were ready to fulfill them unquestioningly not only for fear but for conscience' sake. He sent his generals and adjutants there where he wanted to penetrate with his personal supervision and personal command. They were to be always ready to leave on various and often sensitive errands. With their assistance Nicholas controlled the army, he sent them to inspect military units, to supervise recruitment, etc.; he sent them to investigate abuses in civil and military economy and demanded detailed reports to him personally. Such errands were a means of direct interference of supreme authority with all kinds of matters and issues: on investigation of the activities of civil and military authorities. . ${ }^{25}$

From our point of view, the text by A. Presnyakov contains most precise components of the definition of an agent. Historiography has paid little attention to the adjutants of the retinue as one of the most efficient and frequently used instrument of power. The all-purpose role of adjutants makes any generalized judgment about their functional duties vulnerable. During the reign of Nicholas I, adjutants had different fates and different motives to serve in the retinue; sometimes their retinue title be-

23 B.V. Anan'ich, ed., Power and Reforms. From Autocratic to Soviet Russia [in Russian] (St Petersburg: Dmitrii Bulanin, 1996), 272.

${ }^{24}$ Centenary of the Ministry of War. 1802-1902. Imperial Headquarters. History of the Sovereign's Retinue. The Reign of Nicholas I, 13 vols., vol. 2 (St Petersburg: Tipografiya tovarishchestva M.O. Vol'fa, 1908), 7-117.

25 A.E. Presnyakov, "The Apogee of Autocracy" [in Russian], in Russian Autocrats, comp. A.F. Smirnov (Moscow: Kniga, 1990), 286-87. 
came honorary and did not involve any "sensitive assignments," as A. Presnyakov put it. On the other hand, those who were given such "sensitive assignments" were apparently vested with the personal trust of the monarch. The higher was the degree of trust, the lower could become the influence of the formal institutions in the sphere which such agent was responsible for. Probably, trust must be defined as the basis of the nature of a close agent; and his appearance as an inspector or a supervisor changed the behavior of the officials who faced him as a "figure of distrust" representing the monarch.

After resignation in 1824, Prince A. Menshikov came back to serve on his personal request, which the emperor granted, and was reinstated in the highest retinue rank of Adjutant General on October $10,1826 .{ }^{26}$ In this capacity, he was part of a small circle of those who could potentially count on being given personal assignments in solving various important tasks.

However, the appearance of Menshikov in the navy can be considered in a broader aspect, that of the influence of land department practices on the maritime administration, because some of the officers of the General Staff and clerical officials of the Ministry of War came to the administrative military positions in the navy together with Menshikov. The appointment of the military officers to "critical" spheres was a distinctive feature of higher administration under Nicholas I. It is already a more substantiated and well-described fact in historiography. ${ }^{27}$ The military department, which became a model during the reform, was centralized and well-structured. It was its order that Menshikov and his assistants were supposed to implement in the navy.

The appointment of military or retinue "agents" as proxies for Nicholas I to resolve important issues should be considered in the context of general readiness of the bureaucratic apparat and low efficiency of its operation at that time. During the reign of Alexander I, new institutions appeared which lent administrative structures some features of European kind. However, the problem of the lack of qualified officials who would serve the abstract ideals of law and order, new administrative forms, rules and instructions had not yet been resolved. Post-Weberian research of bureaucracy, in particular P. Blau's, points out that the administration of power based on bureaucratic rules and discipline must be distinguished from the power which is based on professional qualifications. ${ }^{28}$ In the late 1820 s, professional well-established bureaucracy was still quite far ahead. However, while the realia of state administration were be-

${ }^{26}$ Formulyarnye spiski knyazya A.S. Menshikova i otstavka [Record of service of Prince A.S. Menshikov and resignation]. F. 19, op. 4, d. 791, 1. 66 ob. RGA VMF.

${ }^{27}$ W.B. Lincoln, Nicholas I, Emperor and Autocrat of all the Russians 1796-1855 (Bloomington; London: Indiana University Press, 1978), 99-100.

${ }^{28}$ P.M. Blau, "Studies of Formal Organizations" [in Russian], in American Sociology. Prospects. Problems. Methods (Moscow: Progress, 1972), 102. 
coming more and more complicated, the state had a great need for transparent and efficient administration which would be as little dependent on personal connections and nepotism as possible. The main feature of bureaucratic administration is impersonality and non-connectedness of its decisions with the personal interests of an official. The literature describes examples of the increasing level of bureaucratization when an organization changes its head "due to the fact that the head who is unfamiliar with informal practice is forced to rely on official methods of carrying out his orders." ${ }^{29}$ In a situation of distrust of the source of power (the emperor) of the whole administrative structure, the principle of appointing a manager who had not previously had any relation to the sphere in question can be interpreted as a completely effective technique for achieving the result required by the supreme power.

Thus, an agent in the 1820 s - 1830s can be considered as a tool of the mechanism, still "manual" in many respects, by means of which, however, quite highquality bureaucratic structure of the naval ministry was formed where the dominance of personal influence and interests was eliminated. To a certain extent, this confirms the thesis that patrimonial administration can both develop "bureaucratic features" 30 and create high-quality administrative systems of a rational type at a certain level of development. What functions did such agents have and what tasks did they perform?

Contrary to all historical anecdotes about Menshikov, the idea of a "land" manager at the head of the navy (or only its economic part) was admitted by the representatives of the maritime community or, at least it was discussed by them. For instance, considerations about the "land" general can be found in the notes on the condition of the Russian navy in 1824 by V. Golovnin ${ }^{31}$ and in special notes written by the Decembrist sailor D. Zavalishin for consideration by the Committee to Organize the Fleet. ${ }^{32}$ However, in addition to solving managerial problems, the emperor ordered Menshikov to engage in naval affairs at the end of November 1826, pursuing his own goal: the prince was supposed to become a kind of auditor of the maritime administration, having no personal relationship or connections with it. And according to one of the memoirists, the understanding of this very role of Menshikov resulted in the discontent of the maritime community, which was "like a kind of a separate

${ }^{29}$ P.M. Blau with reference to the studies of A.W. Gouldner. See Blau, "Studies of Formal Organizations," 102.

${ }^{30}$ Volkov, "Patrimonialism versus Rational Bureaucracy," 38.

${ }^{31}$ Michman Morekhodov [V.M. Golovnin], On the Condition of the Russian Navy in 1824 [in Russian] (St Petersburg: Tipografiya Morskogo ministerstva, 1861), 63.

32 O rassmotrenii $\mathrm{v}$ Komitete obrazovaniya flota zapisok leitenanta Zavalishina, zaklyuchayushchikh zamechaniya ob obrazovanii flota i dr. [On consideration by the Committee to Organize the Fleet of the notes by Lieutenant Zavalishin, containing remarks on the establishment of the fleet et al.]. F. 148, op. 1, d. 148, 1. 3. RGA VMF. 
state. ${ }^{, 33}$ Another memoirist described the technique of appointing pretended deputies to acting ministers as a tried and tested method of removing the latter from power in a situation where the tsar no longer trusted them. ${ }^{34}$ It seems that such position of Menshikov was useful for the supreme authority.

The figure of the emperor's agent made an impression of the emperor's detachment from what was happening. In this new scenario, the main initiator of which was the emperor himself, yesterday's honored admirals became the object of distrust, audits and penalties. In the history of reforming the maritime department, Nicholas I always played a major role, which inevitably had to involve him in interpersonal conflicts, including those related to corruption, abuse of power, non-observance of instructions, illegal dismissals of those "out of favor," etc. But that was the range of issues pertaining to the monarch to deal with. For instance, Nicholas I devoted much time to Kronstadt and personally inspected the port. On January 17, 1827 A. Benckendorff wrote to M. Vorontsov that Admiral Moller (senior)

was removed from his posts in Kronstadt and dismissed for open and proven abuses in his administration. Today the emperor has just left for Kronstadt, where he will appear out of the blue; he is accompanied by Menshikov alone, who is entrusted with putting the Admiralty clerical affairs in order. It is a great choice and it is what he studied diligently and continually... 35

A few days later, on January 22, Menshikov wrote in his diary that on the order of the tsar he demanded a certificate from Moller explaining the reason for the dismissal of a ship master. ${ }^{36}$

As Menshikov entered naval affairs, the level of visible personal presence (but not participation) of the emperor decreased, thus creating an illusion of his detachment from the naval group of interests. However, any situation of conflict or disloyalty to the actions of the agent himself exposed his vulnerability and the essence of his nature. For example, when an anonymous denunciation of Menshikov's actions in the navy was received during his absence from St Petersburg, his first "client" Flügel Adjutant V. Perovsky begged the emperor not to gather the admirals in order to establish the author of the denunciation: this would make everyone think, firstly, that the emperor believed denunciations, and secondly, that the emperor showed distrust of

${ }^{33}$ K.I. Fisher, Sketches of a Senator [in Russian] (Moscow: Zakharov, 2008$), 77$.

${ }^{34}$ F.F. Vigel', Sketches [in Russian] (Moscow: Zakharov, 2008), 312.

${ }^{35}$ Letter from A.Kh. Benckendorff to M.S. Vorontsov. St Petersburg, January 17, 1927, in Personal Files of Prince Vorontsov, 40 vols., vol. 35 (Moscow: Universitetskaya tipografiya, 1889), 272.

${ }^{36}$ Dnevniki knyazya A.S. Menshikova [Diaries of Prince Menshikov]. F. 19, op. 7, d. 134, 1. 88 ob. RGA VMF. 
Menshikov and allowed discussing his decisions. ${ }^{37}$ Having heeded the arguments of V. Perovsky, Nicholas I changed his mind, since in fact the discussion of Menshikov's actions with the admirals based on denunciation would ultimately mean criticism of his own decisions and his personal choice of Menshikov as the head of the fleet. It was decided to ignore the denunciation.

Personal participation of the emperor in resolving conflict situations raised the issue of the monarch's responsibility for the decisions made and also of involving his name in an awkward context. In the matter of getting information, Nicholas I relied on the bodies of the police which he had established and for preventing public reprimand, there were agents and Menshikov became one of them. The prince understood the purpose of his role. Many years later, in 1857, while preparing commentaries on the draft of the department reform under Grand Duke Konstantin Nikolayevich, Menshikov warned the Admiral General against direct management of the economic section of the fleet because money and contract matters should not involve the name of a member of the imperial family. ${ }^{38}$ On the tide of liberal transformations, such position was perceived as retrograde, reflecting "backward" views of the person who personified military and naval department and in addition to that had a negative experience of commanding the army during the Crimean War. But Menshikov's position reflected his experience in the administration of the Grand Duke's father. In 1827, when the Grand Duke was born, Menshikov was turning into the figure who was responsible for everything that happened to the fleet in the eyes of the society and in official documents; at the same time, the drama of his position was that Prince Menshikov himself was more likely to carry out the duties he was charged with (especially during the first years of reforms in 1826-28) than to act in accordance with his own views on this or that subject. The tsar acted through him, going into the heart of those matters which could have been regarded as unworthy of "the highest attention."

37 "Delo ob anonimnom donose na knyazya Menshikova s rezolyutsiyami gosudarya" [File of the anonymous denunciation of Prince Menshikov with the instructions of the sovereign]. F. 19, op. 4, d. 74, 1. 21 ob. RGA VMF.

38 Zamechaniya knyazya Menshikova po sostavleniyu proekta preobrazovaniya Morskogo ministerstva [Commentary of Prince Menshikov on drafting the reform of the Naval Ministry]. F. 19, op. 1, d. 331, 1. 35 ob. RGA VMF; K.V. Donik, "Prince A.S. Menshikov and Administrative Transformations in the Maritime Department in the Late 1850s" [in Russian], in Alexander II and his Time. To the 200th Anniversary of His Birth (St Petersburg: RGPU im. A.I. Gertsena, 2019), 143-55. 


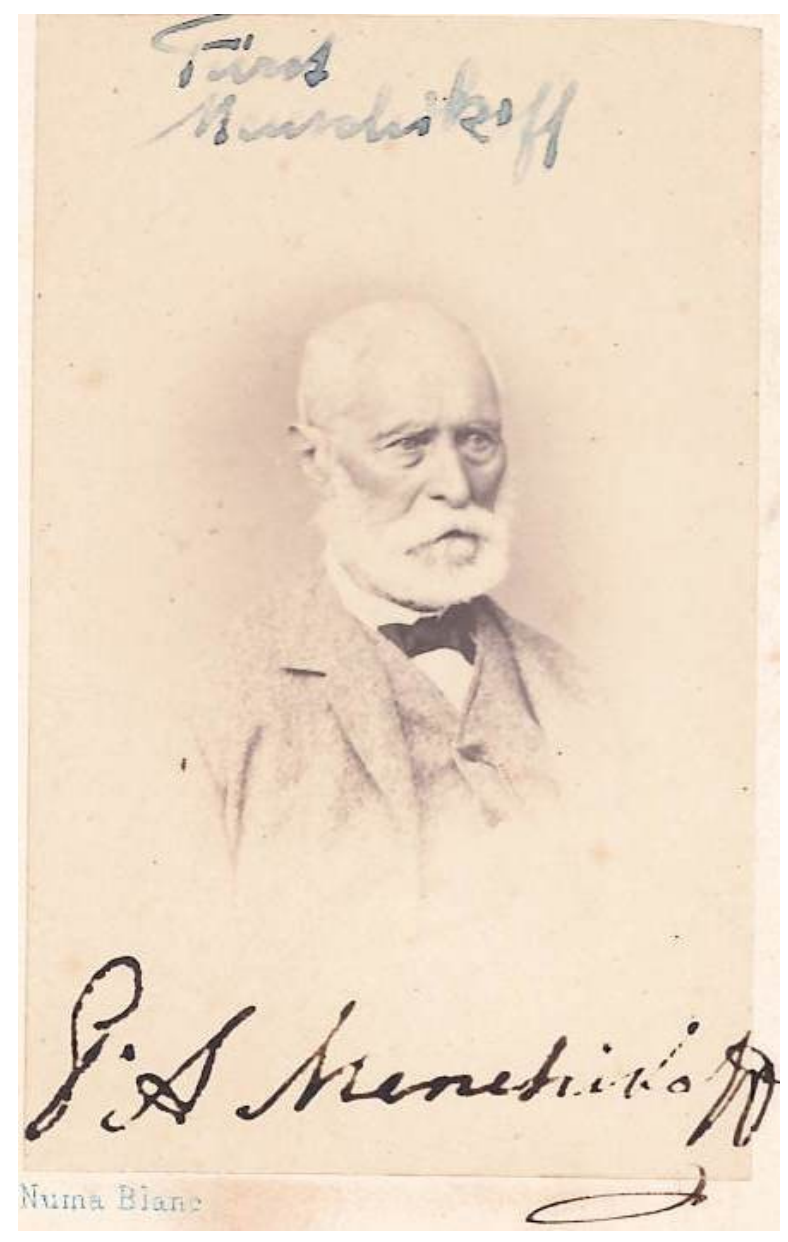

Prince A.S. Menshikov, 1860s.

Published for the first time. Photo from the personal collection of K.V. Donik

The problem of possible personal criticism against the monarch himself and against his decisions by the society was described by M. Florinskii based on the material of the early twentieth century. ${ }^{39}$ Being a kind of payment for the autocrat's power which no institutions could limit, it consisted in the fact that "the corresponding orders, at least outwardly, looked like the fruits of the tsar's personal initiative with all the ensuing consequences." ${ }^{40}$ Under Nicholas I, the intervention of the supreme power in the administrative bureaucratic system intensified, as the emperor sought to make it "fulfill its duties diligently" 41 but at the same time the burden of his personal responsibility became heavier. Therefore, Menshikov's function can be

${ }^{39}$ M.F. Florinskii, “Autocracy, Bureaucracy and the Problem of the Monarch's Irresponsibility in the $19^{\text {th }}-$ Early $20^{\text {th }}$ centuries" [in Russian], in Historical Knowledge: Traditions and Innovations: materials of the International Theoretical Conference. Izhevsk, October 26-28, 1993. Pt. 2 (Izhevsk: Izdatel'stvo Udmurtskogo universiteta, 1996), 5-14. Accessed April 25, 2020, http://annales.info/rus/19/florinskiy.htm.

${ }^{40}$ Florinskii, "Autocracy, Bureaucracy and the Problem of the Monarch's Irresponsibility."

${ }^{41}$ Florinskii, "Autocracy, Bureaucracy and the Problem of the Monarch's Irresponsibility." 
compared with a sort of a "screen" which provided both the appearance of the monarch's non-involvement and secrecy, in which Nicholas I preferred to operate.

This does not mean that no one had an idea of what was going on in the naval ministry (some memoirists testify to that), but it does not seem to be discussed in the context of the personal interest of the monarch, personal decisions despite the ideas of justice or of what was customary. First of all, among the sailors themselves. And since in reality Menshikov's mission was a personal order of the tsar to deal with nepotism, corruption and reform the navy at the same time, it did not fit into any historiographical scenario which would explain his actions.

From the very beginning of its existence, the position of an agent also structured official access to the emperor, who deliberately created the practice of transferring orders to the head of the navy Moller through Menshikov. Beginning with the first rescript addressed to the chief of the naval staff dated December 4, 1826, informing that Menshikov was assigned to him, ${ }^{42}$ drafts of decrees, rescripts and other "replies" of Nicholas I were prepared by Menshikov, approved by the tsar and sent to Moller through Menshikov. Nicholas I read all Menshikov's drafts, made corrections and signed if necessary. Menshikov kept drafts and copies of royal decrees without submitting them to the naval offices; the emperor returned especially important secret documents with the resolution specifically stipulating their non-admission to the office records or archives. The report Moller was obliged to deliver to the emperor as the naval minister and chief of staff was actually duplicated by Menshikov's weekly reports on the subjects of his mission.

Finally, the last function of the agent should be given special consideration. That function was connected with the actual fulfillment of Menshikov's assignment. Referring once again to the above quoted historiography on adjutants, it must be emphasized that the tasks assigned to them were completely different. ${ }^{43}$ Prince A. Menshikov was entrusted with the creation of the administrative structure of naval administration according to the plan which had been adapted for the naval department by the emperor himself. He carried out this assignment first on paper, drafting a legislative basis for the functioning of the future ministry's apparat, and then in practice, transferring the entire department to new organizational tracks. At the same time, he oversaw all the senate and adjutant revisions which were carried out at the time and reported to the emperor about their progress.

The implementation of so large-scale a task was impossible without reliable support of assistants standing at the lower rungs of the administrative ladder. To solve it, the agent himself also formed a "toolkit" which was represented by a combination of

42 O naznachenii knyazya Menshikova dlya preobrazovaniya Morskogo ministerstva [On the appointment of Prince Menshikov to reform the naval ministry]. F.19, op. 4, d. 17, 1. 17. RGA VMF.

${ }^{43}$ Presnyakov, "The Apogee of Autocracy," 293. 
formal bureaucratic elements and informal ones. Prince A. Menshikov is known in historiography for "starting a reshuffle in the system of the Maritime Department." The anatomy of the new department and the nature of the "reshuffle" deserve a separate study.

How did the sailors perceive the monarch's agent without a position who was engaged in naval reforms? According to K. Fischer, a famous memoirist, a senator, who was aide to the prince for special commissions in the late 1820 s, Menshikov understood that his stay in the role of a reformer of the fleet could not please the old sailors. $^{45}$

However, the understanding that Menshikov was endowed with trust and practically unlimited access to the sovereign made the heads of expeditions, departments and chanceries reconcile with the fact of his invasion in the "separate state." The officials were obliged to inform him of the subject of their occupation. In his diary entries for December 1826, the prince noted the days when different naval officials visited him. ${ }^{46}$ Thus, already at the beginning of 1827 , Menshikov became the main figure in the navy, whose position was determined by the monarch's trust and mission.

\section{Conclusion}

Summarizing the above, it should be noted that the situation of the reform in 1826-28 was unique in the history of the navy and was reflected in documentary evidence from the personal files of Prince A. Menshikov. Nicholas I's requirement of absolute secrecy of all the details of what was going on in the navy behind the facade of the administrative reform naturally contributed to the fact that the role of Prince A. Menshikov seemed more than unknown, and in the context of his non-maritime past, even illogical. The historiography of the imperial time could not say anything more, staying within the limits of official historical writing. Nevertheless, even the discovery and analysis of all the circumstances of Menshikov's appearance in the naval ministry, his first steps in the administration, his relations with the tsar and the naval elite do not lead to a simple and unambiguous interpretation of the events associated with his figure. They suggest a search for appropriate models of interpretation in a number of existing historiographical concepts, condemning the scholarly construction to eclecticism of terminology and approaches.

${ }^{44}$ Anan'ich, Power and Reforms, 273.

${ }^{45}$ Fisher, Sketches of a Senator, 77.

${ }^{46}$ Dnevniki knyazya A.S. Menshikova [Diaries of Prince A.S. Menshikov]. F. 19, op. 7, d. 134, 1. 86. RGA VMF. 


\section{Список литературы}

Андреева E.А., Андреева T.B., Косопкин А.С. и др. Управленческая элита Российской империи. История министерств. 1802-1917. - Санкт-Петербург: Лики России, 2008. - 693 с.

Блау П.М. Исследования формальных организаций // Американская социология. Перспективы. Проблемы. Методы. - Москва: Прогресс, 1972 - С. 93-105.

Бутенин А.B. А.С. Меншиков - государственный деятель, царедворец и человек // Из глубины времен: альманах. - Санкт-Петербург: Редакция альманаха «Из глубины времен», 1995. - Вып. 5. - С. 112-122.

Власть и реформы: от самодержавной к советской России / под редакцией Б.В. Ананьич. - Санкт-Петербург: Дмитрий Буланин, 1996. - 801 с.

Доник К.В. Кронштадтское следствие 1827 г. и князь А.С. Меншиков: к вопросу реформирования флота в начале царствования Николая I // Историческая память России и декабристы. 1825-2015. Сборник материалов международной научной конференции (СанктПетербург, 14-16 декабря 2015 г.). - Иркутск: Иркутский областной историко-мемориальный музей декабристов: Артиздат, 2015. - С. 426-435.

Доник К.В. Князь А.С. Меншиков и административные преобразования в Морском ведомстве в конце 50-х гг. ХІХ столетия // Александр II и его время. К 200-летию со дня рождения: сборник статей / под редакцией В.В. Яковлева. - Санкт-Петербург: РГПУ им. А.И. Герцена, 2019. - С. 143-155.

Лапин В.В. Неудачная погоня // Николай Первый. Молодые годы. Воспоминания. Дневники. Письма. - Санкт-Петербург: Пушкинский фонд, 2008. - С. 5-27.

Мустонен П. Собственная его императорского величества канцелярия в механизме властвования института самодержца, 1812-1858: к типологии основ имперского управления. [Хельсинки] : Aleksanteri inst., 1998. - 357 с.

Огородников С.Ф. Исторический обзор развития и деятельности Морского министерства за сто лет его существования. - Санкт-Петербург: Типография Морского Министерства, 1902. -263 c.

Пресняков A.E. Апогей самодержавия // Российские самодержцы / составитель А.Ф. Смирнов. - Москва: Книга, 1990. - С. 261-319.

Тарле E.B. Крымская война: в 2 т. Т. 2. - Санкт-Петербург: Наука, 2011. - 507 с.

Флоринский М.Ф. Самодержавие, бюрократия и проблема безответственности монарха в XIX - начале XX века // Историческое познание: традиции и новации: материалы Международной теоретической конференции (Ижевск, 26-28 октября 1993 г.). Ч. 2. - Ижевск: Удмуртский университет, 1996. - С. 5-14. - URL: http://annales.info/rus/19/florinskiy.htm (Дата обращения - 25.04.2020).

Чубинский В.Г. Историческое обозрение устройства управления Морским ведомством в России. - Санкт-Петербург: Типография Морского министерства, 1869. - 314 с.

Volkov V. Patrimonialism versus Rational Bureaucracy: On the historical Relativity of Corruption // Bribery and blat in Russia: negotiating reciprocity from the Middle Ages to the 1990s / edited by St. Lovell. - Houndmills, Basingstoke, Hampshire: Macmillan Press; New York: St. Martin's Press, in association with School of Slavonic and East European Studies, University of London, 2000. - P. 35-47.

Hosking G. Patronage and the Russian state // The Slavonic and East European Review. Vol. 78. - No. 2. - 2000. - P. 301-320.

Linkoln W.B. Nicholas I, Emperor and Autocrat of all the Russians, 1796 -1855. - Bloomington; London: Indiana University Press, 1978. - 424 p. 
Orlovsky D.T. Political clientelism in Russia: the historical perspective // Leadership selection and patron-client relations in the USSR and Yugoslavia: Selected Papers from the Second World congress for Soviet and East European Studies (Garmisch-Partenkirchen, 1980). - London: Allen \& Unwin, 1983. - P. 174-199.

Yaney G.L. The Systematization of Russian Government: Social Evolution in the Domestic Administration of Imperial Russia, 1711-1905. - Urbana, Ill.: University of Illinois Press, 1973. $430 \mathrm{p}$.

\section{References}

Anan'ich, B.V., ed. Vlast' i reformy: ot samoderzhavnoi k sovetskoi Rossii [Power and reforms. From autocratic to Soviet Russia]. St Petersburg: Dmitrii Bulanin, 1996. (In Russian)

Andreeva, E.A., T.V. Andreeva, A.S. Kosopkin et al. Upravlencheskaya elita Rossiiskoi imperii. Istoriya ministerstv. 1802-1917 [Administrative Elite of the Russian Empire. The history of ministries. 1802-1917]. St Petersburg: Liki Rossii, 2008. (In Russian)

Blau, P.M. "Issledovaniya formal'nykh organizatsii" [Studies of formal organizations]. In Amerikanskaya sotsiologiya. Perspektivy. Problemy. Metody [American sociology. Prospects. Problems. Methods], 93-105. Moscow: Progress, 1972. (In Russian)

Butenin, A.V. "A.S. Menshikov - gosudarstvennyi deyatel', tsaredvorets i chelovek" [A.S. Menshikov, a statesman, a courtier, and a person]. In Iz glubiny vremen: al'manakh [From the depths of time: an almanac], iss. 5, 112-22. St Petersburg: Redaktsiya al'manakha "Iz glubiny vremen", 1995. (In Russian)

Chubinskii, V.G. Istoricheskoe obozrenie ustroistva upravleniya Morskim vedomstvom v Rossii [Historical review of the management of the Maritime Department in Russia]. St Petersburg: Tipografiya Morskogo ministerstva, 1869. (In Russian)

Donik, K.V. 'Knyaz' A.S. Menshikov i administrativnye preobrazovaniya v Morskom vedomstve v kontse 50-kh gg. XIX stoletiya" [Prince A.S. Menshikov and administrative transformations in the Maritime Department in the late 1850s]. In Aleksandr II i ego vremya. K 200-letiyu so dnya rozhdeniya: sbornik statei [Alexander II and his time. To the 200th anniversary of his birth], edited by V.V. Yakovlev, 143-55. St Petersburg: RGPU im. A.I. Gertsena, 2019. (In Russian)

Donik, K.V. 'Kronshtadtskoe sledstvie 1827 g. i knyaz' A.S. Menshikov: k voprosu reformirovaniya flota $\mathrm{v}$ nachale tsarstvovaniya Nikolaya I" [The Kronstadt investigation of 1827 and Prince A.S. Menshikov: on the issue of reforming the fleet at the beginning of the reign of Nicholas I]. In Istoricheskaya pamyat' Rossii i dekabristy. 1825-2015. Sbornik materialov mezhdunarodnoi nauchnoi konferentsii (Sankt-Peterburg, 14-16 dekabrya 2015 g.) [Historical memory of Russia and the Decembrists. 1825-2015. Collected papers of the international scientific conference (St Petersburg, December 14-16, 2015)], 426-35. Irkutsk: Irkutskii oblastnoi istorikomemorial'nyi muzei dekabristov: Artizdat, 2015. (In Russian)

Florinskii, M.F. "Samoderzhavie, byurokratiya i problema bezotvetstvennosti monarkha v XIX - nachale XX veka" [Autocracy, bureaucracy and the problem of the monarch's irresponsibility in the $19^{\text {th }}$ - early $20^{\text {th }}$ centuries]. In Istoricheskoe poznanie: traditsii $i$ novatsii: materialy Mezhdunarodnoi teoreticheskoi konferentsii. Izhevsk, 26-28 oktyabrya 1993 g. Pt. 2 [Historical Knowledge: Traditions and Innovations: Materials of the International Theoretical Conference. Izhevsk, October 26-28, 1993], 5-14. Izhevsk: Udmurtskii universitet, 1996. Accessed April 25, 2020. http://annales.info/rus/19/florinskiy.htm. (In Russian) 
Hosking, G. "Patronage and the Russian State." The Slavonic and East European Review, vol. 78, no. 2 (2000): 301-20.

Lapin, V.V. "Neudachnaya pogonya" [Unfortunate chase], in Nikolai Pervyi. Molodye gody. Vospominaniya. Dnevniki. Pis'ma [Nicholas I of Russia. Early years. Reminiscences. Diaries. Letters], 5-27. St Petersburg: Pushkinskii fond, 2008. (In Russian)

Linkoln, W.B. Nicholas I, Emperor and Autocrat of all the Russians, 1796-1855. Bloomington; London: Indiana University Press, 1978.

Mustonen, P. Sobstvennaya ego imperatorskogo velichestva kantselyariya $v$ mekhanizme vlastvovaniya instituta samoderzhtsa, 1812-1858: k tipologii osnov imperskogo upravleniya [His Imperial Majesty's Own Chancery in the mechanism of autocrat rule, 1812-1858: on the typology of the foundations of imperial government]. [Helsinki]: Aleksanteri inst., 1998. (In Russian)

Ogorodnikov, S.F. Istoricheskii obzor razvitiya i deyatel'nosti Morskogo ministerstva za sto let ego sushchestvovaniya [Historical review of the development and activities of the naval ministry for a hundred years of its existence]. St Petersburg: Tipografiya Morskogo Ministerstva, 1902. (In Russian)

Orlovsky, D.T. "Political Clientelism in Russia: the Historical Perspective." In Leadership Selection and Patron-client Relations in the USSR and Yugoslavia: Selected Papers from the Second World congress for Soviet and East European Studies (Garmisch-Partenkirchen, 1980), 174-99. London: Allen \& Unwin, 1983.

Presnyakov, A.E. "Apogei samoderzhaviya" [The apogee of autocracy]. In Rossiiskie samoderzhtsy [Russian Autocrats], comp. A.F. Smirnov, 261-319. Moscow: Kniga, 1990. (In Russian)

Tarle, E.V. Krymskaya voina [The Crimean War]. 2 vols., vol. 2. St Petersburg: Nauka, 2011. (In Russian)

Volkov, V. "Patrimonialism versus Rational Bureaucracy: On the Historical Relativity of Corruption." In Bribery and Blat in Russia: Negotiating Reciprocity from the Middle Ages to the 1990s, edited by St. Lovell, 35-47. Houndmills, Basingstoke, Hampshire: Macmillan Press; New York: St. Martin's Press, in association with School of Slavonic and East European Studies, University of London, 2000.

Yaney, G.L. The Systematization of Russian Government: Social Evolution in the Domestic Administration of Imperial Russia, 1711-1905. Urbana, Ill.: University of Illinois Press, 1973.

Ксения Владимировна Доник

Слушатель программы ДПО

Европейского университета в Санкт-Петербурге

Санкт-Петербург, Россия https://orcid.org/0000-0002-7179-5897 extale@mail.ru
Kseniya V. Donik

Student of additional professional education course, European University at St Petersburg St Petersburg, Russia https://orcid.org/0000-0002-7179-5897 extale@mail.ru 